\title{
Flow Cytometry for Rapid Determination of Number of Microbial Cells Grown on Fish
}

\author{
Hideaki ENDO, Junichi NAKAMURA, Huifeng REN and Tetsuhito HAYASHI \\ Department of Food Science and Technology, Tokyo University of Fisheries, Konan, Minato, Tokyo 108-8477, Japan
}

Received April 10, 2002; Accepted July 30, 2002

\begin{abstract}
Application of the flow cytometry (FCM) technique for rapid determination of the total number of microbial cells grown on yellow-fin horse mackerel was described. An ultrasonic treatment was used to remove the cells on seafood samples of yellow-fin horse, Japanese common squid, short-neck, and common octopus. Almost of cells were removed from the samples in 9 min by the treatments. Since seafood products might contain various non-microbial debris particles in addition to microbial cells, propidium iodide was used to discriminate the two groups. A fluorescence histogram distinguished the cells from the particles. The FCM method allowed determination of the number of microbial cells adhering to fish during the preservation period. Cell numbers determined by FCM well paralleled that measured by the raditional colony counting method in the range of $10^{5}-10^{9}$ cells/g. One FCM assay could be completed within $60 \mathrm{~s}$ and the total assay time including preparation of the microbial cells was within $30 \mathrm{~min}$.
\end{abstract}

Keywords: flow cytometry, microbial cell, bacteria, cell numbers, seafood

To enhance food safety and assure the quality of foods, the hazard analysis critical control point (HACCP) system has been employed in the food process. Seafood industry has also now generally adapted quality assurance systems and is implementing the HACCP concept. A rapid monitoring system for microbial cells such as bacteria in seafood is required in these cases.

Direct microscopic counts and colony counts (Postgate, 1969) have traditionally been employed to determine the number of microbial cells. Direct microscopic counts are simple, however, they cannot be applied to a quantity of less than $10^{6}$ cells $/ \mathrm{ml}$. Although colony counts are reliable, the method is time-consuming. Several new methods have been developed for more rapid determination, such as bioluminescent ATP (Tuncan \& Martin, 1987), electrochemical (Matsunaga \& Namba, 1984; Ramsay \& Turner, 1988), ultrasonic (Zips \& Faust, 1989; Endo et al., 1989), and biosensor (Hoshi et al., 1991). Although the bioluminescent ATP method is high sensitive, it is hard to discriminate ATP arising from microbial cells from that remaining in the food sample. Electrochemical and biosensor methods enable us to determine the number of viable cells in less than $10 \mathrm{~min}$, however, in most cases, these cannot be applied to less than $10^{7}$ cells $/ \mathrm{ml}$. The ultrasonic method can be applied to rapid determination but it measures cell density regardless of cell vitality.

In recent years, the application of flow cytometry (FCM) has begun to attract attention for the rapid determination of microbial cell numbers with high sensitivity (Allman et al., 1992; Diaper et al., 1992; Diaper \& Edwards, 1994; Endo et al., 1997; Magarinos et al., 1997; Endo et al., 1998). FCM combines the advantages of microscopic and biochemical analyses for the measurement of physical and biochemical characteristics of individual cells. However, although FCM has also been applied to detect microbial cells in milks and soft drinks in the food industry (Donnelly \& Baigent, 1986; Pettipher, 1991; D'Apice et al.,

E-mail: endo@tokyo-u-fish.ac.jp
1996; Tortorello et al., 1998; Gunasekera et al., 2000), it has not been used to determine the number of cells firmly adhering to the surface of solid food, because the sample for FCM must be prepared as a cell suspension. We have developed a new method for rapid enumeration of bacterial cells on the surface of a surimibased product using the FCM technique described previously paper (Endo et al., 2001). This is based on ultrasonic energy being used to remove bacterial cells from the surface of the product. Ultrasonic treatment has been used to clean the surface of various materials such as metal and glass. In this study, the ultrasonic treatment was used to remove Escherichia coli cells adhering to a surimi-based product as a model experiment. Cell numbers determined by FCM well paralleled those measured by the traditional colony counting method.

The present paper describes the rapid determination of total number of microbial cells grown on fish using this FCM technique with the following steps: 1) preparation of various seafood samples for FCM assay using the ultrasonic treatment, 2) distinction between microbial cells and non-microbial particles in a sample using propidium iodide, and 3) enumeration of microbial cells grown on fish during their preservation period.

\section{Materials and methods}

Materials Seafood samples of yellow-fin horse mackerel Trachurus japonicus, Japanese common squid Todarodes pacificus, short-neck clam Ruditapes philippinarum, and common octopus Octopus vulgaris were purchased from the Tokyo central wholesale market (Tokyo). Propidium iodide (PI) was purchased from Sigma (Mo). Tryptone and yeast extract were obtained from Difco Laboratories (MI). Other chemical reagents were obtained commercially and were of analytical grade.

Ultrasonic treatment to remove microbial cells Sample of yellow-fin horse mackerel, Japanese common squid, and common octopus were cut into cubes (weight: $1.0 \mathrm{~g}$, size: ca. $10 \times 10 \times 10 \mathrm{~mm}$ ) with an outer surface of $1 \mathrm{~cm}^{2}$. Since the same 
size cube of short-neck clam was difficult to prepare, a whole shucked shellfish body was used as a sample and the result was divided by its sample weight $(2.0-2.5 \mathrm{~g})$ to obtain " $\mathrm{CFU} / \mathrm{g}$ ". Each sample was incubated for $0-24 \mathrm{~h}$ at $25^{\circ} \mathrm{C}$ and then $3 \mathrm{ml}$ of $0.9 \% \mathrm{NaCl}$ solution (saline) was added to a test tube containing $1.0 \mathrm{~g}$ of the sample. The sample was treated by ultrasonic vibration for $0-15 \mathrm{~min}$ at $5^{\circ} \mathrm{C}$ using an ultrasonic cleaner (Sharp Co., type: UT-205, oscillating frequency: $35 \mathrm{kHz}$, effective output: $200 \mathrm{~W}$ ) to remove the microbial cells from the sample cube.

After ultrasonic treatment, the rate of recovery microbial cells was obtained using the following formula: $A /(A+B)=100(\%)$ in which ' $A$ ' is the number of cells in saline prepared by ultrasonic treatment of the sample cube, and ' $B$ ' is the number of cells left within the cube and liberated by homogenization. The determination of microbial cell numbers was carried out on the saline suspending microbial cells (sample A) treated with ultrasonic vibration and the homogenate prepared with $3 \mathrm{ml}$ of saline from the remaining cube (sample B) after the ultrasonic treatment. One milliliter of sample (A) or sample (B) was spread over the surface of agar plates and the colonies were counted as described later.

FCM assay for microbial cells After ultrasonic treatment,
(A)

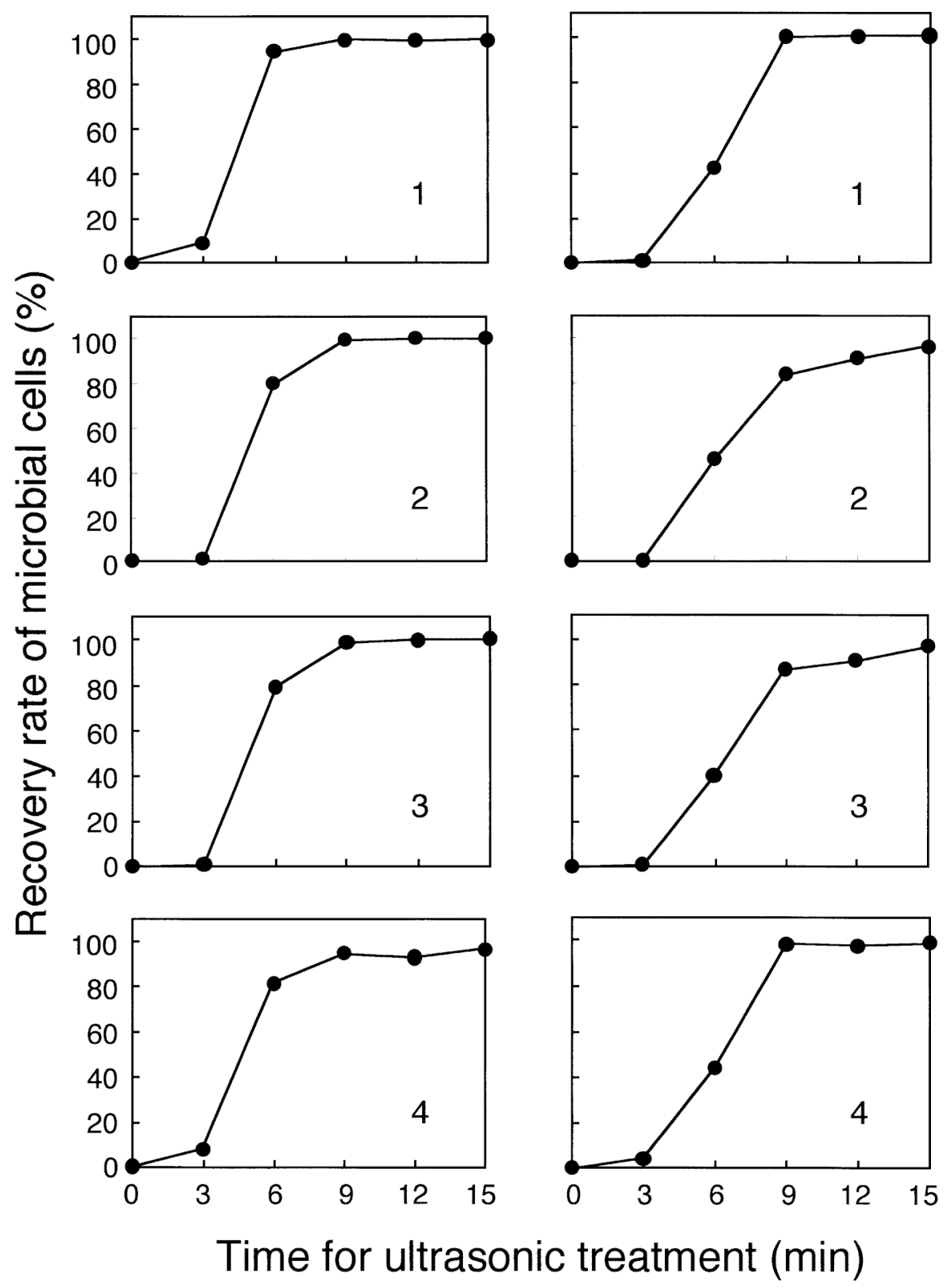

Fig. 1. Effect of ultrasonic treatment time on the recovery rate of the microbial cells. (A) The seafood samples were purchased from the market and the sample was sonicated immediately. (B) The samples were handled as "A", incubated at $25^{\circ} \mathrm{C}$ for $24 \mathrm{~h}$, and then treated with ultrasonic vibration. 1; yellow-fin horse mackerel Trachurus japonicus, 2; Japanese common squid Todarodes pacificus, 3; short-neck clam Ruditapes philippinarum (shucked shellifish), 4; common octopus Octopus vulgaris. The number of microbial cells of each sample was as follows: yellow-fin horse mackerel: (A) $1.9 \times 10^{5} \mathrm{CFU} / \mathrm{g}(\mathrm{B}) 6.1 \times 10^{7} \mathrm{CFU} / \mathrm{g}$, Japanese common squid: (A) $7.7 \times 10^{5} \mathrm{CFU} / \mathrm{g}$ (B) $3.9 \times 10^{7} \mathrm{CFU} / \mathrm{g}$, common octopus: (A) $6.3 \times 10^{5} \mathrm{CFU} / \mathrm{g}$ (B) $3.9 \times 10^{6} \mathrm{CFU} / \mathrm{g}$ and short-neck; (A) $6.9 \times 10^{5} \mathrm{CFU} /$ g (B) $3.6 \times 10^{7} \mathrm{CFU} / \mathrm{g}$. 
the saline suspending the microbial cells was transferred to a test tube and then heated at $90^{\circ} \mathrm{C}$ for $10 \mathrm{~min}$ for fixation of the cells. The fixed cells were transferred into PI solution (final concentration: $20 \mu \mathrm{g} / \mathrm{ml}$ ) and incubated at $25^{\circ} \mathrm{C}$ for $10 \mathrm{~min}$. Because PI penetrates intact cells very slowly but can rapidly enter damaged cells. The stained cells were washed $\left(1700 \times g, 5 \mathrm{~min}, 4^{\circ} \mathrm{C}\right)$ and suspended with saline prior to FCM assay. FCM was performed using EPICS XL (Coulter Co., FL) equipped with an argon laser. The power output was $15 \mathrm{~mW}$ and the $488 \mathrm{~nm}$ wavelength was used to excite the fluorescent probes. Light scattered in the forward light scatter was filtered by a $488 \mathrm{~nm}$ narrow band-pass filter and collected by photo-multiplier. The fluorescent emission from PI, excited at $488 \mathrm{~nm}$, was detected at 605-635 nm with a FL3 photo-multiplier. The fluorescent signal was gated using manual-gating regions. To establish optimum conditions for cell counting, the discriminator value was varied from 0 to 100 . The stop time for the passage of the sample was set at $60 \mathrm{~s}$, and an event number was measured as the number of microbial cells.

Conventional colony counting method The homogenate of each seafood sample or the saline suspension after ultrasonic treatment was diluted with saline to obtain a final number of microbial cells of 30-300 cells per $100 \mu \mathrm{l}$. The cells were spread over the surface of agar plates consisting of $(\mathrm{g} / \mathrm{l})$ : tryptone (5), yeast extract (2.5), $\mathrm{NaCl}(5)$, and agar (15). The triplicate plates assured for accuracy. The plates were incubated for 2-3 days at $20^{\circ} \mathrm{C}$ and the colonies were counted.

\section{Results and Discussion}

Ultrasonic treatment to remove the microbial cells from the surface of seafood samples Figure 1 shows the effect of the ultrasonic treatment time on the recovery rate of the microbial cells from the surface of the various samples. The horizontal axis represents time of ultrasonic treatment and the recovery rate of the cells from the surface of the seafood is plotted along the vertical axis. In Fig. $1 \mathrm{~A}$, the seafood samples were purchased from the market and the sample was then subjected to the ultrasonic

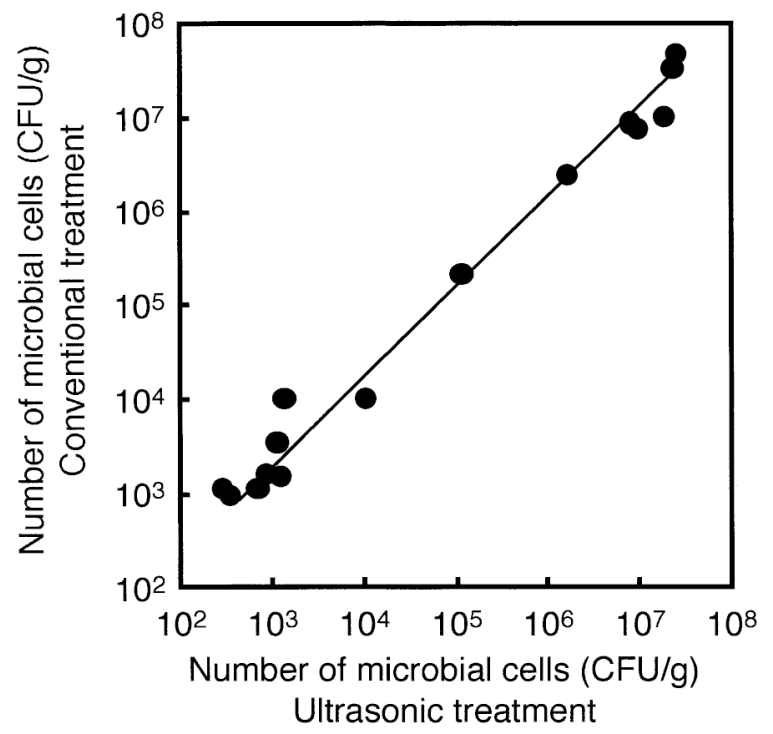

Fig. 2. Correlation between the total number of microbial cells on fish determined by using the ultrasonic and conventional treatments. Yellow-fin horse mackerel was used as a model seafood sample. treatment immediately. When the treatment time was set at 6-9 min, most cells were removed from the surface of each sample. Alternatively, the sample was incubated at $25^{\circ} \mathrm{C}$ for $24 \mathrm{~h}$ prior to ultrasonic treatment shown in Fig. 1B. As these figures indicate, when the treatment time was set above 9 min, more than $95 \%$ of cells could be removed from the surface of samples of the mackerel, octopus, and clam. A treatment time for 12 min was necessary for the squid. A longer treatment time was required when the microbial cells had been allowed to grow on fish, perhaps because of an increase in the number of adherent cells.

Comparison between the number of microbial cells determined using the ultrasonic and conventional treatments The ultrasonic treatment was applied to determine cell numbers on the surface of the model fish (yellow-fin horse mackerel) by the colony counting method. The treatment time was set at $9 \mathrm{~min}$ according to the above results. After ultrasonic treatment, the saline suspending the microbial cells was spread over the surface of agar plates and the colonies were counted after incubation. The conventional treatment was also administered as follows: the diluted homogenate prepared from $1.0 \mathrm{~g}$ of a sample cube as shown in Materials and Methods was spread over the surface of the agar plates, and then the colonies were counted in the manner described above. Figure 2 shows the comparison of the total number of microbial cells on fish determined by two methods. A good correlation was observed by plotting them on logarithmically $\left(y=4.38 x^{0.91}, \mathrm{R}^{2}=0.98\right)$ in the range of $10^{2}-10^{7} \mathrm{CFU} / \mathrm{g}$. These results show that the ultrasonic treatment was quite effective to leave microbial cells from the surface of sample surface.

Effect of the discriminator on the determination of cell numbers In this study, the number of microbial cells was measured by counting an event number of FCM. However, the value of the event number was readily influenced by the debris in the sample and by light scattering. For this reason, it was necessary to establish favorable assay conditions by varying the discriminator. A discriminator is a channel setting for a parameter allowing events below the setting to be ignored, and it can eliminate a signal caused by debris. Figure 3 shows a correlation between the

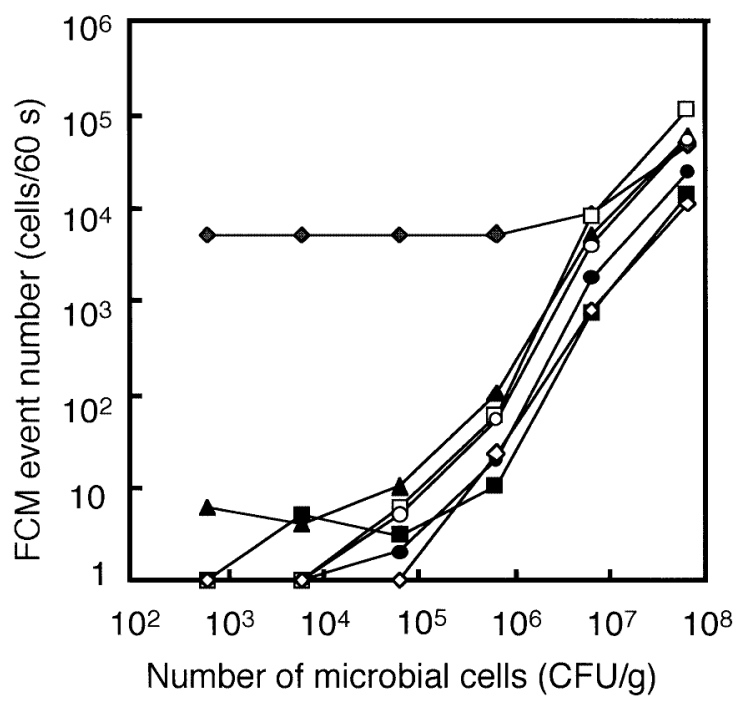

Fig. 3. Effect of the discriminator on the event number of FCM. The values of the discriminator were as follows: $\bullet, 0 ; \mathbf{\square}, 10 ; \boldsymbol{\Delta}, 20 ; \square, 40 ; \bigcirc, 60 ; \bullet$, $80 ; \diamond, 100$. The stop time of FCM was set at $60 \mathrm{~s}$. 


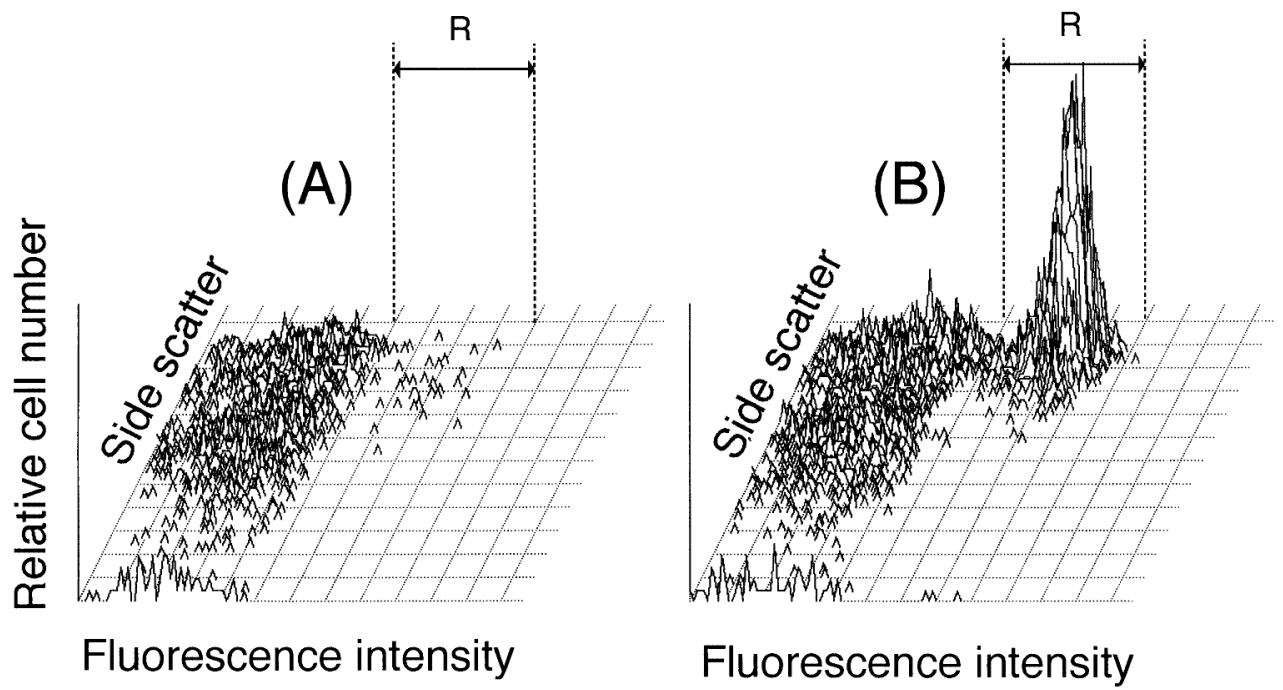

Fig. 4. Fluorescence histograms for microbial cells and non-microbial particles on fish. Yellow-fin horse mackerel was used as a model sample. (A) The sample without microbial cells (The sample was washed well with sterilized water), (B) The sample containing microbial cells (10 $\mathrm{CFU} / \mathrm{g}$ ). The conditions for the FCM assay were as follows: discriminate value, 60; stop time, $60 \mathrm{~s}$.

event number (cells/60 s) and the number (cells/ml) of cells isolated from yellow-fin horse mackerel for various values of the discriminator. The cells were stained with PI $(20 \mu \mathrm{g} / \mathrm{ml})$. As shown in this figure, when the discriminator was set at 0 , the event number did not change with the cell concentration in the range of $10^{2}-10^{7} \mathrm{CFU} / \mathrm{g}$. This observation may be attributable to the effects of the cell debris or light scattering. On the other hand, when the value of the discriminator was set above 10, the event value increased with the cell concentration. A linear correlation was observed between the two parameters when the discriminator was set at 60 , showing the potential for determination of microbial cell numbers by FCM. Therefore, all subsequent experiments were performed at this value.

The distinction between microbial cells and non-microbial particles with PI In this study, PI was used as fluorescent probe to discriminate microbial cells from the non-microbial particles, because seafood products might contain various non-microbial particles such as debris of the sample. Figure 4 shows fluorescence histograms of FCM for samples stained with PI. The $\mathrm{x}$ axis represents PI fluorescence intensity, the $y$-axis represents the side scatter intensity which provides information about cell shape, density, and surface morphology, and the relative cell numbers are plotted along the z-axis. Sample (A) was yellow-fin horse mackerel containing few microbial cells and sample (B) contained microbial cells $\left(10^{6}\right.$ cell $\left./ \mathrm{g}\right)$. In the histogram of Fig. 4A, most particles possessed low fluorescence intensity, whereas high intensity was observed as shown in Fig. 4B. This phenomenon assumed that since sample (B) contained microbial cells, PI passed into the cells through the cell membrane, intercalated into double-stranded nucleic acid molecules and fluoresced (Edidin, 1970). By contrast, in the case of sample (A), low fluorescence intensity was observed. For this reason, the particles in sample

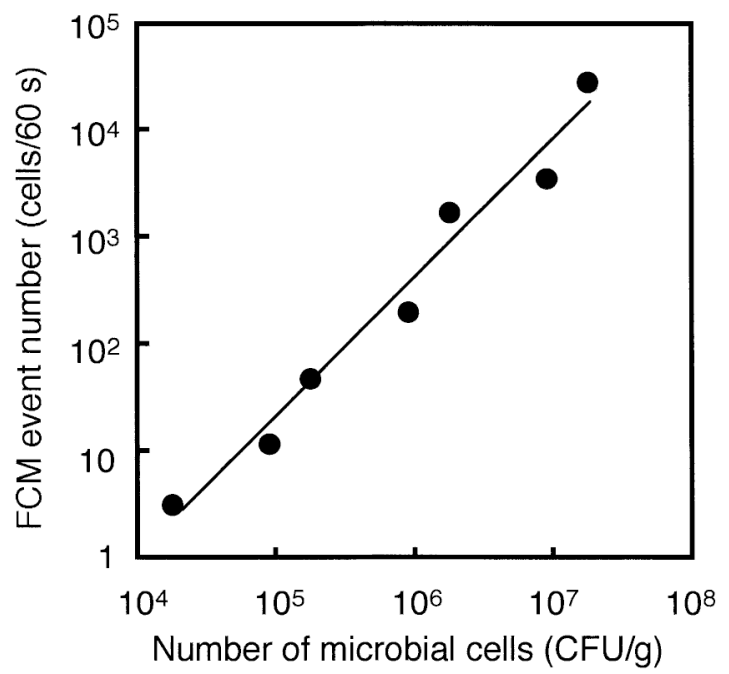

Fig. 5. Calibration curve for microbial cells on the surface of fish. Yellowfin horse mackerel was used as a model sample. The FCM assay conditions were same as those in Fig. 4.

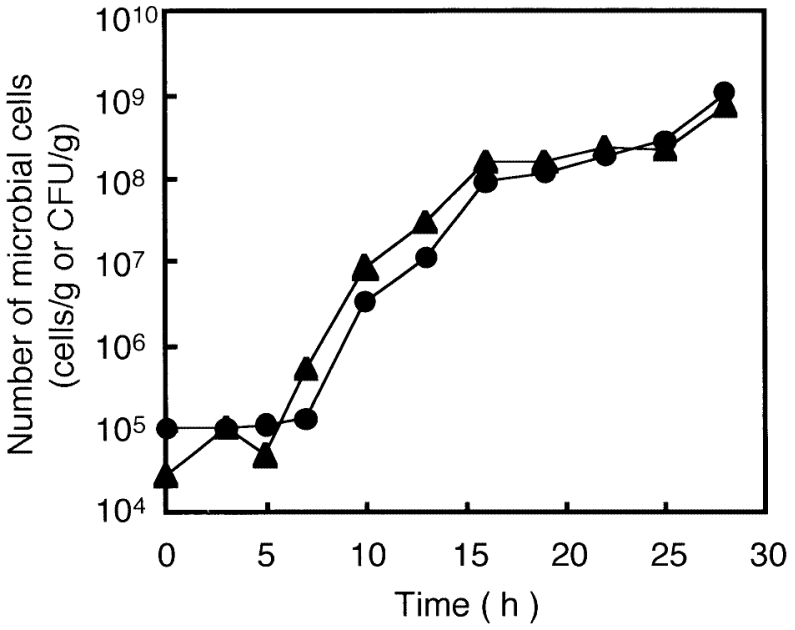

Fig. 6. Time course of number of microbial cells on the surface of fish

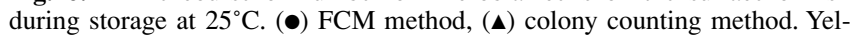
low-fin horse mackerel was used as model sample. The FCM assay conditions were the same as in Fig. 4. 
(B) could not possess double-stranded nucleic acid. Therefore, these micro-particles might be non-microbial materials such as debris resulting from ultrasonic treatment. In Fig. 4, a linear region $(\mathrm{R})$ was drawn in the histograms and was adjusted to distinguish between the microbial cells and non-microbial particles, that is, the particles within region $(\mathrm{R})$ are regarded as microbial cells, stained with PI, and those outside of $(\mathrm{R})$ are considered the non-microbial particles. Thus, it is possible to discriminate microbial cells from the non-microbial particles.

Determination of the Microbial Number by FCM

Calibration curve for microbial cells on the surface of fish Figure 5 shows a calibration curve for microbial cells on the fish surface. The horizontal axis represents the number of these cells determined by colony counting method and the vertical axis represents the event number of FCM. Yellow-fin horse mackerel was incubated at $25^{\circ} \mathrm{C}$ for $24 \mathrm{~h}$, and the sample cube was treated with ultrasonic vibration. After treatment, the saline suspending the microbial cells was diluted with $0.9 \% \mathrm{NaCl}$ solution randomly for FCM and the colony counting methods. As shown in the figure, a linear relationship between the two methods was observed by plotting them logarithmically $\left(\mathrm{y}=9 \cdot 10^{-6}\right.$ $\left.x^{1.27} \cdot \mathrm{R}^{2}=0.96\right)$ in the range of $1.8 \times 10^{5}-1.9 \times 10^{8}$ cells $/ \mathrm{g}$. Although measurement of cell numbers less than $10^{4} \mathrm{CFU} / \mathrm{g}$ was difficult, it was possible to determine low concentrations by increasing the sample volume. For example, if $1 \mathrm{ml}$ of sample containing $10^{4}$ cells was passed through the cytometer at $100 \mu \mathrm{l} / \mathrm{min}$, then it would be possible to detect $10^{5}$ events in $10 \mathrm{~min}$.

Determination of number of cells on a fish during its preservation period The FCM method was applied to determine the number of microbial cells adhering to the surface of yellow-fin horse mackerel during preservation. Figure 6 shows the time course of cell numbers in the sample determined by FCM and the colony counting methods. The sample of fish was preserved at $25^{\circ} \mathrm{C}$ for $0-28 \mathrm{~h}$ and all analytical procedures were the same as in Fig. 4. The cell numbers determined by FCM were calculated from the regression equation of the calibration curve shown in Fig. 5.

In Fig. 6, the cell numbers determined by the colony counting method increased with time up to $25 \mathrm{~h}$. The value determined by FCM also increased and the final cell number was almost the same (ca. $8 \times 10^{8}$ cell $/ \mathrm{g}$ ). Cell numbers determined by FCM well paralleled those measured by traditional method along with time in the range of $10^{5}-10^{9}$ cells/g. For a period of from 5 to $20 \mathrm{~h}$, the measurements of FCM were slightly lower than those by the conventional counting. At present, the reason for this phenomenon is unclear but it was possible to monitor the number of microbial cells over a period of time. One FCM assay could be completed within $60 \mathrm{~s}$ and the total assay time including the preparation of bacteria was within $30 \mathrm{~min}$. In conclusion, our proposed method using the FCM technique can be useful in rapidly determining the number of microbial cells grown on a fish sample.
Acknowledgment This research was supported in part by a Grant-in-aid for Scientific Research from Japanese Ministry of Education, Culture, Sports, Science and Technology.

\section{References}

Allman, R., Hann, A.C., Manchee, R. and Lloyd, D. (1992) Characterization of bacteria by multiparameter flow cytometry. J. Appl. Bacteriol., 73, 438-444.

D’Apice, L., Fenizia, D., Capparelli, R., Scala, F. and Iannelli, D. (1996). Detection of antibodies to Staphylococcus aureus in water buffalo milk by flow cytometry. Res. Vet. Sci., 60, 179-181.

Diaper, J.P., Tither, K. and Edwards, C. (1992). Rapid assessment of bacterial viability by flow cytometry. Appl. Microbiol. Biotechnol., 38, 268-272.

Diaper, J.P. and Edwards, C. (1994). The use of fluorogenic esters to detect viable bacteria by flow cytometry. J. Appl. Bacteriol., 77, 221-228.

Donnelly, C.W. and Baigent, G.J. (1986). Method for flow cytometric detection of Listeria monocytogenes in milk. Appl. Environ. Microbiol., 52, 689-695.

Edidin, M. (1970). A rapid, quantitative fluorescence assay for cell damage by cytotoxic antibodies. J. Immunol., 104, 1303-1306.

Endo, H., Sode, K., Ogura, K., Ohya, K. and Karube, I. (1989). Determination of microbial concentration with a piezoelectric gum sensor. J. Biotechnol., 12, 307-316.

Endo, H., Nakayama, J., Hayashi, T. and Watanabe, E. (1997). Application of flow cytometry for rapid determination of cell numbers of viable bacteria. Fish. Sci., 63, 1024-1029.

Endo, H., Nakayama, J., Ushio, H., Hayashi, T. and Watanabe, E. (1998). Application of flow cytometry for rapid detection of Lactococcus garvieae. Appl. Biochem. Biotechnol., 75, 295-306.

Endo, H., Nagano, Y., Ren, H. and Hayashi, T. (2001). Rapid enumeration of bacteria grown on surimi-based product by flow cytometry. Fish. Sci., 67, 969-974.

Gunasekera, T.S., Attfield, P.V. and Veal, D.A. (2000). A flow cytometry method for rapid detection and enumeration of total bacteria in milk. Appl. Environ. Microbiol., 66, 1228-1232.

Hoshi, M., Nishi, H., Hayashi, T., Okuzumi, M. and Watanabe, E. (1991). Development of biosensor for the determination of total viable bacteria cell count. Bull. Jpn. Soc. Sci. Fish., 57, 281-285.

Magarinos, B., Romalde, J.L., Cid, A. and Toranzo, A.E. (1997). Viability of starved Pasteurella piscicida in seawater monitored by flow cytometry and the effect of antibiotics on its resuscitation. Lett. Appl. Microbiol., 24, 122-126.

Matsunaga, T. and Namba, Y. (1984). Detection of microbial cells by cyclic voltammetry. Anal. Chem., 56, 798-801.

Pettipher, G.L. (1991). Preliminary of flow cytometry for detection of yeast in soft drinks. Lett. Appl. Microbiol., 12, 109-112.

Postgate, J.R. (1969). Viable counts and viability. Methods Microbiol., 1, 611-621.

Ramsay, G. and Turner, A.P.F. (1988). Development of an electrochemical method for the rapid determination of microbial concentration and evidence for the reaction mechanism. Anal. Chim. Acta, 215, 61-69.

Tortorello, M.L., Reineke, K.F., Stewart, D.S. and Raybourne, R.B. (1998). Comparison of methods for determining the presence of Escherichia coli $\mathrm{O} 157: \mathrm{H} 7$ in apple juice. J. Food. Prot., 61, 14251430.

Tuncan, E.U. and Martin, S.E. (1987). Lysostaphin lysis procedure for detection of Staphylococcus aureus by the firefly bioluminescent ATP method. Appl. Environ. Microbiol., 53, 88-91.

Zips, A. and Faust, U. (1989). Determination of biomass by ultrasonic measurements. Appl. Environ. Microbiol., 55, 1801-1807. 